Article

\title{
Genetic diversity analysis of the Mexican Lidia bovine breed population and its relation with the Spanish population by using a subset of SNPs under low gametic disequilibrium
}

\section{Análisis de diversidad genética en la población de la Raza de Lidia Mexicana y su relación con la población española por medio de un panel de SNPs con bajo desequilibrio gamético}

Paulina García Eusebi ${ }^{\mathrm{a}^{*}}$,

Oscar Cortés Gardyn ${ }^{\mathrm{b}}$,

Susana Dunner Boxberger ${ }^{\mathrm{b}}$,

Javier Cañón Ferreras ${ }^{\mathrm{b}}$

${ }^{\text {a } U n i v e r s i d a d ~ A u t o ́ n o m a ~ d e ~ B a r c e l o n a . ~ E s p a n ̃ a . ~}$

${ }^{\mathrm{b}}$ Universidad Complutense de Madrid. España.

Autor de correspondencia: paulinaeusebi@gmail.com

\begin{abstract}
- Abstract:
Retaining features of the auroch (Bos taurus primigenius), the Lidia bovine is a primitive breed originated $\sim 250 \mathrm{yr}$ ago in the Iberian Peninsula, where is still distributed, along with France and several American countries. Selected upon a behavior, which enhances their aggressiveness; these bovines were raised to participate in popular festivities that nowadays reinforce the identity of regional cultures. Different festivities demanded diverse behavior patterns, prompting a fragmentation of the breed into small lineages. In Mexico, where these bovines reached high popularity, mainly two families of breeders imported Lidia bovines from Spain in the early XX century specializing their production either reproducing the new arrivals among them or realizing systematic crosses with local populations. Genetic diversity and structure of the Mexican and Spanish Lidia populations has been assessed with microsatellite data, but nowadays SNP molecular markers allows higher resolution level. Genetic diversity of the Mexican and Spanish Lidia populations and their relationship were
\end{abstract}


assessed by using 573 SNPs with a low gametic disequilibrium $\left(\mathrm{r}^{2}<0.01\right)$ from the $50 \mathrm{~K}$ BeadChip on 468 individuals from both populations. In both populations, similar gene diversity values were observed. Significant $F_{I S}$ values in both populations means strong subdivision, higher $F_{S T}$ genetic distances were observed in the Spanish than in the Mexican population. Genetic structure analysis showed similarity of three Spanish lineages with González family and some Llaguno breeders, but most Llaguno family clustered separated: genetic differentiation along with high gene diversity suggest an introgression of creole cattle in the constitution of the Mexican population.

Key words: Lidia breed, Behavior selection, Population differentiation, Genetic structure, SNP.

\section{- Resumen:}

El bovino de Lidia pertenece a una raza primitiva originada $\approx 250$ años en la Península Ibérica, lugar donde aún se distribuye junto con diversos países de América. Seleccionados por un comportamiento que potencia la agresividad, estos bovinos fueron criados para participar en festividades populares que en la actualidad refuerzan la identidad de las culturas regionales. Diferentes festividades han demandado la selección de diferentes comportamientos, desencadenando una fragmentación de la raza en linajes. En México donde este ganado alcanzó gran popularidad, principalmente dos familias de criadores importaron de España bovinos a comienzos del siglo XX, especializando la producción. La diversidad genética y estructura de las poblaciones mexicanas y españolas han sido evaluadas con microsatélites, pero hoy en día los marcadores de tipo SNP permiten una mayor resolución. En este sentido se analizó la diversidad genética de la población mexicana de Lidia y se evaluó su relación con la española utilizando 573 SNPs con bajo desequilibrio de ligamiento $\left(r^{2}<0.01\right)$. En ambas poblaciones se observaron similares valores de diversidad genética. Valores significativos de $F_{I S}$ en ambas poblaciones significan una subdivisión de linajes, también se observaron mayores distancias genéticas $F_{S T}$ en la población española que en la mexicana. El análisis de estructura genética mostró similitud de tres linajes españoles con la familia González y algunos criadores de la familia Llaguno; pero la mayor parte de la familia Llaguno se agrupó separada: esta diferenciación así como la alta diversidad genética sugieren una introgresión de ganado criollo en la constitución de la población mexicana.

- Palabras clave: Raza de Lidia, Selección por comportamiento, Diferenciación poblaciones, Estructura genética, SNP.

Recibido 02/03/2017.

Aceptado 20/05/2017. 


\section{Introduction}

Possessing multiple ancient features of their earliest forms originated from the auroch (Bos taurus primigenius), and distinguished by its extensive management ${ }^{(1)}$, the Lidia bovine is a primitive breed whose roots can be traced back to approximately $250 \mathrm{yr}$ ago in the Iberian Peninsula in order to satisfy a demand of cattle destined to participate in popular spectacles. At present, shows involving cattle are found in geographical areas comprising mainly the southwest region of Europe (Italy, France, Spain and Portugal) and along the American continent involving approximately 14 countries $^{(2)}$. These kinds of spectacles have their origins in the early Mediterranean civilizations, where bovines of untamed behavior, lacking of docile temperament, participated in ceremonies and rituals as an assigned symbol of the nature's strength ${ }^{(3)}$. After, in the $13^{\text {th }}$ Century those practices evolved into social events called tauromachies or "tauromaquias", a term that makes reference of a cultural and subjective representation of all types of games involving cattle and not as a single term for identifying one single practice (since sometimes the term is associated exclusively with the Spanish bullfight or "corrida"). To date, tauromaquias assemble a social and semantic construction, are an important livestock economic source and reinforce local and regional identities of the countries where are still found ${ }^{(2,4)}$. Diversity in orography and climate along with historical factors and traditions, led place to the development of different variants of bovine populations. There all were selected based upon behavioral performance of aggressiveness: the Andalusian and Navarro-Aragonese that in Spain gave rise to the original Lidia breed population, in Portugal the Lidia Portuguese breed and in France the Landaise and Camargue's cattle populations ${ }^{(5)}$.

The specialization and intensification of animal husbandry did not take place until $250 \mathrm{yr}$ ago with the emergence of many specialized breeds during the industrial revolution. In Spain, to become breeder of this type of cattle provide more status to the members of aristocracy and gentry, who in search of improving the behavioral skills of their "aggressive" bovines developed a documented breeding system, giving rise to the original Lidia breed population $^{(4,6)}$. Moreover, these breeders concerned about raising bovines that could be distinguished for performing different type of behavior (sometimes demanded for the different type of festivities) established closed family trees that prompted to a fragmentation of the racial group into small lineages ${ }^{(7)}$.

In America, specifically in Mexico, bovines with these behavioral characteristics were imported during the colonial period (after the conquest of the Aztec empire in 1521) to take part in the festivities that were inherited as traditions of the Spanish colonizers ${ }^{(2)}$. The Lidia breed specialization began between 1908 and 1912 when mainly two families of breeders (Llaguno and González) imported a reduced number of Spanish Lidia bovines. Each family 
kept different breeding strategies, the Llaguno family followed a closed breeding scheme reproducing the new imported animals among them, and the González family reproduced the imported animals with local Mexican bovines selected for aggressiveness ${ }^{(8)}$.

Mexican Lidia census suffered dramatic losses during the post-revolution period, which lasted ten years (1910-1920). After those years, breeders recovered their Lidia production opting for raise cattle that derived either from the Llaguno or González families. In recent years, during 1996 and 1997, some Mexican breeders imported close to 1,000 Spanish Lidia bovines before closing borders of importations from $\operatorname{Spain}^{(9)}$. To date, this recent refreshment suggests a strong impact in the genetic structure of the herds belonging from the breeders that took part in those importations. But still, the major part of the Mexican Lidia population derives from the elder Llaguno and González families ${ }^{(8)}$. Despite both Mexican and Spanish Lidia populations are demographically well stablished, their low effective population size places them at risk of extinction ${ }^{(7)}$.

Previous studies on the Spanish Lidia population found a genetic uniqueness in the breed, which is given by a high genetic differentiation between lineages ${ }^{(6)}$. Moreover, Eusebi et al ${ }^{(10)}$ studied the genetic diversity of the Mexican Lidia population and its divergence from the Spanish Lidia population and found high genetic differentiation among them. However, both studies have been conducted by using neutral autosomal microsatellites, and recently, the availability of SNP panels allow the investigation of livestock genetic diversity and genetic structure at higher level of resolution, hard to reach with other types of markers.

In this study, a subset of 573 SNPs with low gametic disequilibrium were selected from the 50K medium density genotyping array (Illumina Inc., San Diego, CA) to assess the genetic diversity and structure of the Mexican and Spanish Lidia populations and thereafter analyze the relationships among these two populations, in order to explore the degree of admixture among them.

\section{Material and methods}

Blood samples of 468 Lidia bovines were collected: 119 belonging to the Mexican population and 349 to the Spanish population. Classification of the Spanish lineages was given according to Cañón et $a l^{(6)}$ and, for the Mexican Lidia population the samples arise from 20 breeders studied independently but classified into the family that they belong to (González or 
Llaguno), according to standards set by the by the Mexican Lidia Breeders Association ${ }^{(9)}$. More information is available in Table1.

Table 1. Description of the Mexican and Spanish populations (Pop) analyzed by SNP markers, providing names of breeders, their acronyms, number of breeders (NB) and $(\mathrm{N})$ number of samples analyzed

\begin{tabular}{|c|c|c|c|c|c|c|c|c|c|c|}
\hline Pop & Family & Name & Acronym & NB & $\mathbf{N}$ & Pop & Name & Acronym & NB & $\mathbf{N}$ \\
\hline \multirow{20}{*}{ 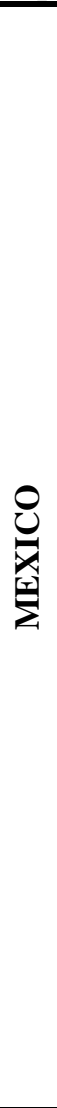 } & \multirow{17}{*}{ 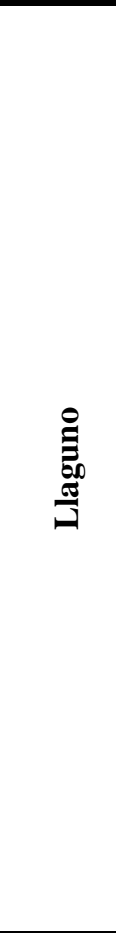 } & $\begin{array}{l}\text { Celia } \\
\text { Barbabosa } \\
\end{array}$ & BAR & 1 & 6 & \multirow{28}{*}{$\frac{Z}{\bar{s}}$} & Albaserrada & ALB & 3 & 14 \\
\hline & & $\begin{array}{l}\text { Boquilla del } \\
\text { Carmen }\end{array}$ & BOQ & 1 & 6 & & Anastasio Martín & ANA & 1 & 6 \\
\hline & & Corlomé & CRL & 1 & 6 & & Antonio Pérez & ANT & 1 & 9 \\
\hline & & Los Encinos & ENC & 1 & 5 & & Araúz de Robles & ARA & 1 & 10 \\
\hline & & $\begin{array}{l}\text { Fernando de la } \\
\text { Mora }\end{array}$ & FER & 1 & 6 & & $\begin{array}{l}\text { Atanasio } \\
\text { Fernández }\end{array}$ & ATA & 3 & 14 \\
\hline & & Garfias & GAR & 1 & 6 & & Baltasar Iban & BAL & 2 & 12 \\
\hline & & La Antigua & IGU & 1 & 6 & & Carlos Núñez & CAR & 4 & 9 \\
\hline & & San José & JOS & 1 & 6 & & Santa Coloma & $\mathrm{COL}$ & 8 & 36 \\
\hline & & Marrón & MAR & 1 & 6 & & Contreras & $\mathrm{CON}$ & 3 & 10 \\
\hline & & \begin{tabular}{|l|} 
San Mateo \\
\end{tabular} & MAT & 1 & 6 & & Conde de la Corte & $\mathrm{COR}$ & 1 & 10 \\
\hline & & Montecristo & MON & 1 & 6 & & José Marzal & CRM & 1 & 9 \\
\hline & & Reyes Huerta & REY & 1 & 6 & & Cuadri & CUA & 1 & 7 \\
\hline & & Fermín Rivera & RIV & 1 & 6 & & Domecq & $\mathrm{DOM}$ & 5 & 29 \\
\hline & & Teófilo Gómez & TEO & 1 & 6 & & Félix Gómez & FEL & 1 & 9 \\
\hline & & $\begin{array}{l}\text { Torreón de } \\
\text { Cañas }\end{array}$ & TOR & 1 & 6 & & Gamero Cívico & GAM & 3 & 16 \\
\hline & & Xajay & XAJ & 1 & 6 & & Hidalgo Barquero & HID & 3 & 15 \\
\hline & & \begin{tabular}{|l|} 
Arroyo Zarco \\
\end{tabular} & ZAR & 1 & 6 & & Manuel Arranz & MAN & 1 & 9 \\
\hline & \multirow{3}{*}{ 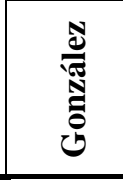 } & \begin{tabular}{|l} 
Carlos \\
Castañeda \\
\end{tabular} & CAS & 1 & 6 & & Conde de la Maza & MAZ & 1 & 3 \\
\hline & & De Haro & HAR & 1 & 6 & & Miura & MIU & 1 & 9 \\
\hline & & Rancho Seco & SEC & 1 & 6 & & Murube & MUR & 4 & 16 \\
\hline & & & & & & & Pablo Romero & $\mathrm{PAB}$ & 1 & 9 \\
\hline & & & & & & & Pedrajas & PED & 2 & 10 \\
\hline & & & & & & & Saltillo & SAL & 3 & 15 \\
\hline & & & & & & & Concha y Sierra & SIE & 1 & 10 \\
\hline & & & & & & & Urcola & URC & 1 & 7 \\
\hline & & & & & & & Veragua & VER & 2 & 16 \\
\hline & & & & & & & Vega Villar & VEG & 4 & 17 \\
\hline & & & & & & & $\begin{array}{l}\text { Marqués de } \\
\text { Villamarta }\end{array}$ & VIL & 2 & 13 \\
\hline
\end{tabular}

Animals were randomly chosen according to their origin, and qualified veterinarians collected the samples during routine practices in the framework of official programs aimed at applying preventive medicine. Blood samples were maintained in Magic Buffer® DNA 
solution $^{(11)}$ until DNA extraction by standard phenol/chloroform methods ${ }^{(12)}$. Genotypes were obtained with the Illumina 50k BeadChip (Illumina Inc., San Diego, CA) and SNP quality was analyzed with the Genome Studio software (Illumina). Thereupon, by using the PLINK software ${ }^{(13)}$ the dataset of SNPs was filtered according to the following excluding criteria: SNPs located on sexual chromosomes; individuals with $>20 \%$ missing genotypes; SNPs with a minimum allele frequency $<0.01$; markers that did not match Hardy-Weinberg equilibrium expectations $\left(\mathrm{P}<10^{-6}\right)$; and a restricted linkage disequilibrium criterion of $\mathrm{r}^{2}<0.01$; thus assuring low gametic disequilibrium rate among markers. Finally, the information derived from 573 SNPs spanning across all the bovine autosomal chromosomes, were selected.

Statistical estimates of genetic diversity were performed followed by a multifactorial correspondence analysis estimated to quantify genetic diversity; these analyses were carried out with the GENETIX v.4.0.5 software ${ }^{(14)}$. The proportion of mixed ancestries among populations was inferred with STRUCTURE v.2.1. software ${ }^{(15)}$ which uses a hierarchical Bayesian model to infer a population structure from multilocus genotypes and assign each individual into that supposed population, assuming that each individual may have mixed ancestry from different underlying populations. The figurative number of populations or genetic clusters $(K)$ ranged from 2 to 4 with six replicate chains for each value of $K$. The runs sharing maximum likelihood pattern were selected to be displayed in a graphic constructed with the DISTRUCT v.1.1. software ${ }^{(16)}$.

\section{Results}

\section{- Genetic diversity •}

Indicators of genetic diversity estimated per population (Mexican and Spanish) and inbreeding $F_{I S}$ estimates are shown in Table 2. In the analysis of the Mexican population, observed $(\mathrm{Ho})$ and expected heterozygosities $(\mathrm{He})$ ranged from 0.35 (Carlos Castañeda) to 0.48 (Teófilo Gómez) and from 0.35 (Marrón and de Haro) to 0.42 (San José, Fermín Rivera and Teófilo Gómez) respectively. Genetic diversity values from the completely Mexican population were $0.46(\mathrm{He}), 0.43(\mathrm{Ho})$. Regarding $F_{I S}$ estimates, most of the breeders presented negative values, with estimates that fluctuated from -0.17 (Corlomé) to 0.09 (Boquilla del Carmen) and a $F_{I S}$ of 0.06 was obtained when the whole Mexican population was considered. Moreover, genetic diversity indicators in the Spanish population revealed a wider range of values compared to the Mexican population. With $\mathrm{He}$ estimates that goes from 0.26 (Cuadri) to 0.44 (Santa Coloma) and Ho ranging from 0.33 (Gamero Cívico) to 0.46 (Anastasio Martín and José Marzal). Genetic diversity values for the whole Spanish 
population were 0.48 for $\mathrm{He}$ and 0.38 of $\mathrm{Ho}$, and $F_{I S}$ values going from -0.13 (Manuel Arranz) to 0.19 (Santa Coloma), thus evidencing a clear lineage subdivision.

Table 2. Genetic diversity parameters of the Mexican and Spanish Lidia breed populations: expected $(\mathrm{He})$ and observed $(\mathrm{Ho})$ heterozigosities, and $F_{I S}$ inbreeding and significance $(* P<0.01)$

\begin{tabular}{|c|c|c|c|c|c|c|c|c|c|c|}
\hline Pop & Family & Acronym & $\mathrm{He}$ & Ho & $F_{I S}$ & Pop & Acronym & $\mathrm{He}$ & Ho & $\bar{F} F_{I S}$ \\
\hline \multirow{20}{*}{ 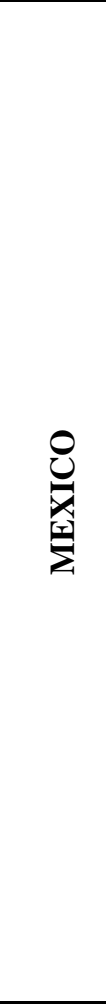 } & \multirow{17}{*}{ 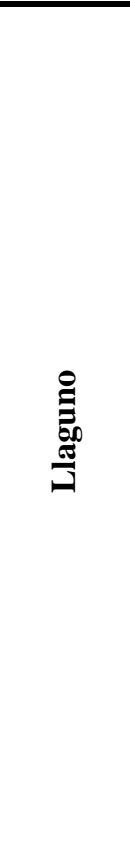 } & BAR & 0.39 & 0.46 & $-0.09^{*}$ & \multirow{28}{*}{$\frac{Z}{\omega}$} & ALB & 0.33 & 0.34 & $0.03^{*}$ \\
\hline & & $\mathrm{BOQ}$ & 0.38 & 0.38 & $0.09 *$ & & ANA & 0.38 & 0.46 & $-0.12 *$ \\
\hline & & CRL & 0.38 & 0.48 & $-0.17 *$ & & ANT & 0.36 & 0.39 & $-0.05^{*}$ \\
\hline & & ENC & 0.39 & 0.41 & 0.07 * & & ARA & 0.32 & 0.37 & $-0.11^{*}$ \\
\hline & & FER & 0.40 & 0.46 & $-0.07 *$ & & ATA & 0.38 & 0.38 & $0.05^{*}$ \\
\hline & & GAR & 0.36 & 0.42 & $-0.04 *$ & & BAL & 0.38 & 0.40 & -0.01 \\
\hline & & IGU & 0.41 & 0.43 & $-0.04 *$ & & CAR & 0.41 & 0.42 & 0.02 \\
\hline & & JOS & 0.42 & 0.45 & $0.04 *$ & & $\mathrm{COL}$ & 0.44 & 0.37 & $0.19^{*}$ \\
\hline & & MAR & 0.35 & 0.40 & 0.02 & & $\mathrm{CON}$ & 0.38 & 0.38 & $0.04 *$ \\
\hline & & MAT & 0.37 & 0.43 & $-0.06^{*}$ & & $\mathrm{COR}$ & 0.34 & 0.38 & $-0.06^{*}$ \\
\hline & & MON & 0.39 & 0.45 & $-0.06^{*}$ & & CRM & 0.39 & 0.46 & $-0.11 *$ \\
\hline & & REY & 0.38 & 0.44 & $-0.05^{*}$ & & CUA & 0.26 & 0.30 & $-0.10^{*}$ \\
\hline & & RIV & 0.42 & 0.44 & $-0.07 *$ & & DOM & 0.41 & 0.39 & $0.08^{*}$ \\
\hline & & TEO & 0.42 & 0.48 & $-0.06^{*}$ & & FEL & 0.35 & 0.37 & -0.01 \\
\hline & & TOR & 0.40 & 0.45 & $-0.06^{*}$ & & GAM & 0.39 & 0.33 & $0.20^{*}$ \\
\hline & & XAJ & 0.39 & 0.44 & $-0.04 *$ & & HID & 0.40 & 0.37 & $0.12 *$ \\
\hline & & ZAR & 0.36 & 0.41 & -0.02 & & MAN & 0.34 & 0.41 & $-0.13^{*}$ \\
\hline & \multirow{3}{*}{ 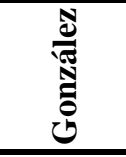 } & CAS & 0.30 & 0.35 & $-0.07 *$ & & MAZ & 0.40 & 0.43 & $0.13^{*}$ \\
\hline & & HAR & 0.35 & 0.40 & $-0.07 *$ & & MIU & 0.34 & 0.39 & $-0.07^{*}$ \\
\hline & & SEC & 0.38 & 0.44 & $0.06^{*}$ & & MUR & 0.39 & 0.36 & $0.11^{*}$ \\
\hline \multicolumn{3}{|c|}{ Value of the whole population } & 0.46 & 0.43 & \multirow[t]{9}{*}{0.06} & & PAB & 0.31 & 0.35 & $-0.06^{*}$ \\
\hline & & & & & & & PED & 0.37 & 0.35 & $0.11^{*}$ \\
\hline & & & & & & & SAL & 0.39 & 0.38 & $0.06^{*}$ \\
\hline & & & & & & & SIE & 0.37 & 0.41 & $-0.06^{*}$ \\
\hline & & & & & & & URC & 0.37 & 0.41 & -0.02 \\
\hline & & & & & & & VEG & 0.39 & 0.34 & $0.15^{*}$ \\
\hline & & & & & & & VER & 0.43 & 0.44 & 0.00 \\
\hline & & & & & & & VIL & 0.41 & 0.42 & 0.02 \\
\hline & & & & & & $\begin{array}{r}\mathrm{V} \\
\text { whol }\end{array}$ & $\begin{array}{l}\text { ue of the } \\
\text { population }\end{array}$ & 0.48 & 0.38 & 0.21 \\
\hline
\end{tabular}

$F_{S T}$ genetic distances were estimated among breeders within breeders (Mexico) and among lineages (Spain) by analyzing each population independently, followed by a second estimation of $F_{S T}$ genetic distances including both, Mexican and Spanish populations (Table 
$3)$. The analysis of the Mexican population revealed average $F_{S T}$ genetic distances going from 0.05 (Marrón) to 0.22 (Carlos Castañeda) when the genetic distance of each breeder to the rest of the breeders is calculated. Also $F_{S T}$ genetic distances of each lineage to the rest of the lineages of the Spanish population ranged from 0.12 (Conde de la Maza) to 0.30 (Cuadri). Wright`s F-statistics $\left(F_{I S}\right.$ and $F_{S T}$ ) in the Mexican population were lower (Value of the whole Mexican population of $F_{S T} 0.10$ and $F_{I S} 0.06$ ) comparing with values obtained in the Spanish population (Value of the whole population of $F_{S T} 0.18$ and $F_{I S} 0.21$ ).

Table 3. $F_{S T}$ genetic distances of the Mexican and Spanish Lidia populations with significance $P<0.05$

\begin{tabular}{|c|c|c|c|c|c|c|c|c|}
\hline Pop & Family & Acronym & $F_{S T^{(I)}}$ & $F_{S T^{(2)}}$ & Pop & Acronym & $F_{S T} T^{(I)}$ & $F_{S T^{(2)}}$ \\
\hline \multirow{20}{*}{ 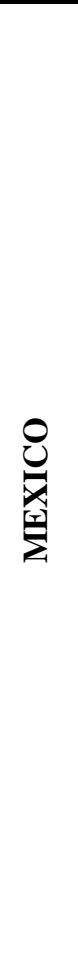 } & \multirow{17}{*}{ 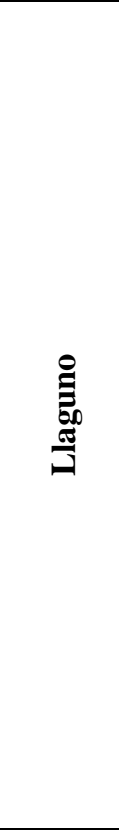 } & BAR & 0.08 & 0.14 & \multirow{28}{*}{$\frac{Z}{\text { Z }}$} & ALB & 0.26 & 0.24 \\
\hline & & $\mathrm{BOQ}$ & 0.07 & 0.15 & & ANA & 0.17 & 0.17 \\
\hline & & CRL & 0.12 & 0.16 & & ANT & 0.20 & 0.21 \\
\hline & & ENC & 0.09 & 0.14 & & ARA & 0.25 & 0.25 \\
\hline & & FER & 0.10 & 0.14 & & ATA & 0.18 & 0.18 \\
\hline & & GAR & 0.09 & 0.16 & & $\mathrm{BAL}$ & 0.19 & 0.19 \\
\hline & & IGU & 0.11 & 0.18 & & CAR & 0.15 & 0.15 \\
\hline & & JOS & 0.09 & 0.12 & & $\mathrm{COL}$ & 0.13 & 0.12 \\
\hline & & MAR & 0.05 & 0.11 & & $\mathrm{CON}$ & 0.20 & 0.19 \\
\hline & & MAT & 0.12 & 0.18 & & COR & 0.22 & 0.23 \\
\hline & & MON & 0.09 & 0.16 & & CRM & 0.17 & 0.17 \\
\hline & & REY & 0.07 & 0.14 & & CUA & 0.30 & 0.30 \\
\hline & & RIV & 0.09 & 0.16 & & DOM & 0.15 & 0.16 \\
\hline & & TEO & 0.08 & 0.15 & & FEL & 0.22 & 0.22 \\
\hline & & TOR & 0.10 & 0.12 & & GAM & 0.17 & 0.17 \\
\hline & & XAJ & 0.06 & 0.13 & & HID & 0.16 & 0.16 \\
\hline & & ZAR & 0.06 & 0.13 & & MAN & 0.22 & 0.22 \\
\hline & \multirow{3}{*}{ 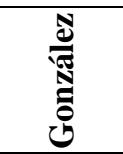 } & CAS & 0.22 & 0.25 & & MAZ & 0.12 & 0.11 \\
\hline & & HAR & 0.15 & 0.18 & & MIU & 0.23 & 0.23 \\
\hline & & SEC & 0.10 & 0.12 & & MUR & 0.18 & 0.18 \\
\hline \multicolumn{3}{|c|}{ Value of the whole population } & 0.10 & & & PAB & 0.26 & 0.26 \\
\hline & & & & & & PED & 0.18 & 0.18 \\
\hline & & & & & & SAL & 0.19 & 0.17 \\
\hline & & & & & & SIE & 0.20 & 0.20 \\
\hline & & & & & & URC & 0.18 & 0.18 \\
\hline & & & & & & VEG & 0.18 & 0.18 \\
\hline & & & & & & VER & 0.14 & 0.14 \\
\hline & & & & & & VIL & 0.16 & 0.16 \\
\hline & & & & & \multicolumn{2}{|c|}{$\begin{array}{c}\text { Value of the whole } \\
\text { population }\end{array}$} & 0.18 & \\
\hline
\end{tabular}

$F_{S T}^{(1)}$ is the average $F_{s t}$ genetic distance from each lineage to the rest of the lineages from the same population. $F_{S T}{ }^{(2)}$ is the average $F_{s t}$ genetic distance from each lineage to the rest of the lineages of both Mexican and Spanish populations. 


\section{- Population relationships and clustering •}

The Bayesian approach implemented in STRUCTURE software ${ }^{(15)}$ was used to analyse the clustering and genetic relationship among both Mexican and Spanish populations, acronyms are stated as defined in Table 1, displaying names of the breeders and their belonging family of the Mexican population, and names of the lineages of the Spanish population. The contribution of the assumed ancestral populations is graphically presented in Figure 1, with $K$ populations going from 2 to 4 .

Figura 1. Analysis of the genetic structure of the Mexican breeders and the Spanish lineages, the plot shows common genetic ancestors, or model based population assignments $(\mathrm{K})$, for values going from from $\mathrm{k}=2$ (upper) to $\mathrm{k}=4$ (lower)
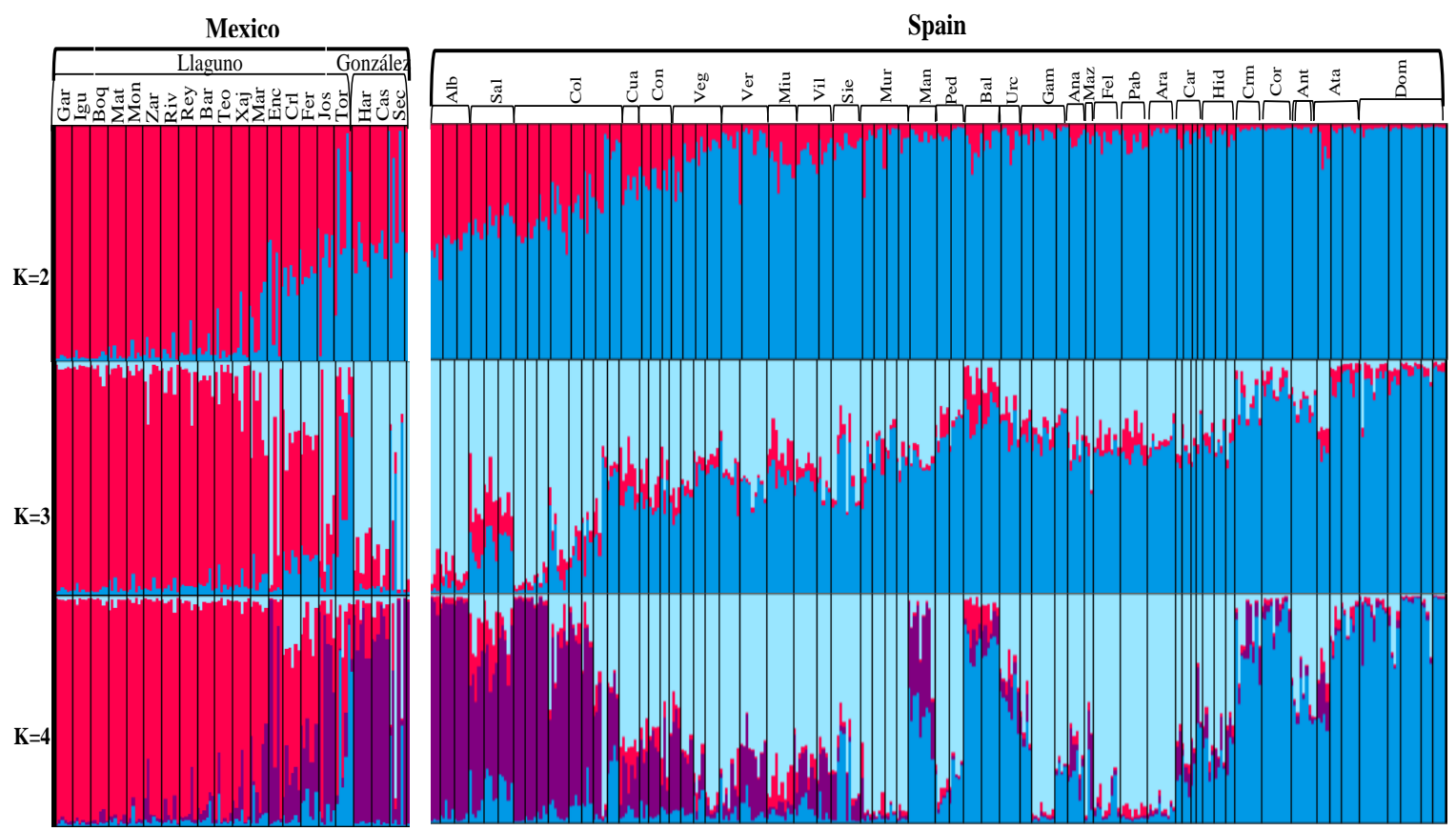

The acronyms are as defined in Table 1 and each acronym encloses the number of breeders belonging to each lineage.

In the Mexican population, from $k=2$ to $k=4$ a single ancestral population is observed in most of the breeders of the Llaguno family (Gar, Igu, Boq, Mat, Mon, Zar, Riv, Rey, Bar, Teo, Xaj and Mat), with a clear separation between González and Llaguno families. Mixed contributions with some of the Spanish lineages (Alb, Sal and Col) are observed in all of the 
González breeders (Sec, Cas and Har) and some breeders from Llaguno family (Tor, Jos, Fer, $\mathrm{Crl}$ and Enc) when $k=4$.

In the Spanish population when $k=2$ most of the lineages belong to a same single ancestral population with some mixed contributions observed in Alb, Sal and Col lineages. Then when $\mathrm{k}=4$ three different ancestral groups or clusters are differentiated: one conformed by Alb, Sal and Col lineages, a second cluster conformed by Cua, Con, Veg, Miu, Vil, Sie Mur, Gam, Ana, Maz, Fel, Pab and Ara and a third cluster conformed of Dom, Ata, Ant, Cor, Crm, Bal and Urc.

In general, among Spanish and Mexican populations, both showed different genetic ancestral origin with an exception of mixed contributions in the Mexican breeders of the González family and Tor, Jos, Fer, Crl, and Enc breeders from the Llaguno family with the Spanish lineages of Alb, Sal and Col.

Finally, in the correspondence analysis (Figure 2) a genetic discrimination between the Mexican and Spanish populations can be seen, with some exceptions like Sec and Tor breeders from the Mexican population who are placed closer to the Spanish Lineages than to the Mexican breeders. Furthermore, the Spanish Col, Sal and Alb: lineages are situated closer to the Mexican breeders than to the rest of the Spanish lineages.

Figura 2. Correspondence analysis of the Spanish and Mexican Lidia breed populations

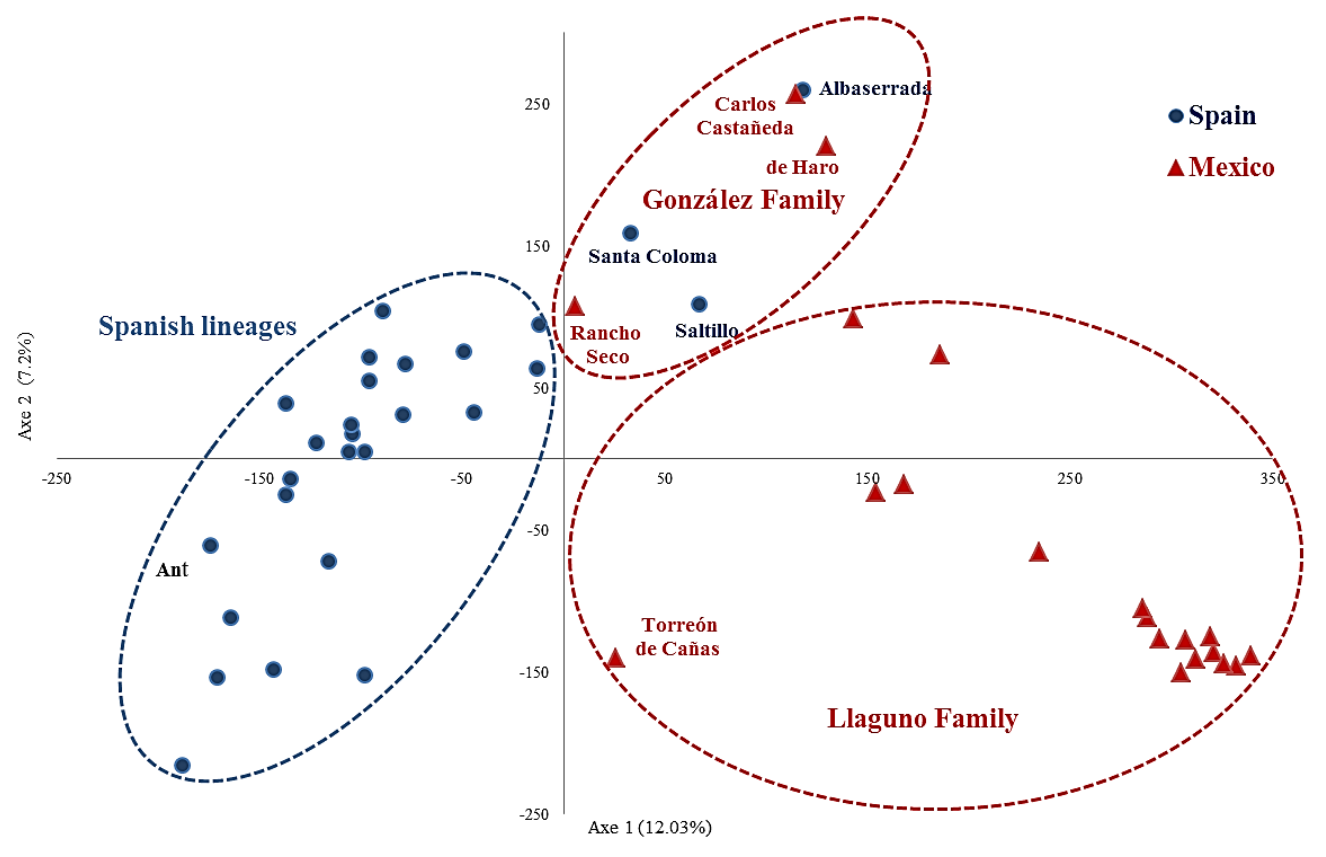




\section{| Discussion}

High gene diversity values were found in both the Spanish (0.48) and the Mexican populations (0.46). This value obtained in the Mexican population is remarkable, since lower gene diversity values were expected to obtain considering that, most of the current Mexican population arose from a few individuals of the Spanish Lidia population. On the contrary, similar diversity values were observed in both populations, so it is reasonable to consider certain degree of introgression with local Creole cattle populations of diverse origin during the establishment of the Mexican Lidia breed population.

Moreover, significant $F_{I S}(P<0.01)$ values were observed in both populations which means a subdivision within each, higher (0.21) in the Spanish than in the Mexican population (0.06). This subdivision in lineages or breeders results in the preservation of more genetic variance $^{(17)}$, but a faster loss of genetic diversity within sub-population can be expected. Additionally, a loss of diversity due to population bottlenecks and founder effects result in increased inbreeding, resulting that the preservation of heterozygosity in the whole population is at the expense of a progressive poor genetic health within each sub-population.

Genetic diversity analysis revealed significantly higher genetic distances $(P<0.05)$ in the Spanish population compared to the genetic distances of the Mexican population, with whole population $F_{S T}$ values of 0.18 and 0.10 respectively (Table 3 ). Similar results were observed by Eusebi $e t a l^{(10)}$ with data obtained with microsatellite markers. In the Mexican population the lower genetic distances among breeders means higher animal exchangeability, a common practice in Mexico and less usual in Spain, where higher genetic distances between lineages were obtained, thus explained by higher genetic isolation among lineages.

Furthermore, genetic structure analysis revealed in both, Correspondence and Bayesian clustering analysis a clear separation among families (González and Llaguno) of the Mexican population and in the Spanish population three clusters are observed at $k=4$. The cluster with Albaserrada (Alb), Saltillo (Sal) and Santa Coloma (Col) is placed closer (correspondence analysis) and share genetic structure with the Mexican González family and some Llaguno breeders (Tor, Crl, Jos and Enc), leaving clearly differentiated the remaining Llaguno breeders. This similarity of Spanish Alb, Sal and Col lineages with the above mentioned González family and the few Llaguno breeders is not surprising, given the fact that those breeders were involved in the imports of 1996 and 1997, introducing mainly animals from Santa Coloma (Col) and in lesser extent Saltillo (Sal) and Vega Villar $(\mathrm{Veg})^{(8)}$. But it is worth to note the proximity of Albaserrada (Alb) lineage to the Mexican population, since 
Albaserrada herds have been raised under strict closed breeding schemes from 1912 onwards $^{(18)}$. This genetic closeness is explained by two similar historical and genetical phenomenons' as Albaserrada lineage derive from Saltillo and Santa Coloma lineages ${ }^{(6)}$ and in parallel, those similar Mexican breeders constructed their herds by mating animals from the same lineages as ancestors.

A deeper analysis of the Mexican population structure revealed that anthropogenic barriers are well documented drivers of the genetic differentiation observed among breeders (e.g., the clear genetic division observed between the González and Llaguno families). Both families where located respectively in the North and south central regions of Mexico and became much like hegemony of Lidia cattle, being in charge to supply Lidia cattle to emerging farmers in their regions. In addition, both families' bovines did not mix each other ${ }^{(8)}$, confirming the different genetic origin among them.

\section{Conclusions and implications}

Isolation along with a small founder population size shaped by a classic bottleneck effect can explain the differentiation of the Llaguno Family of the Mexican population from the Spanish Lineages of which it arose. To all this, a possible introgression of Creole Cattle populations located at the north and south central regions of Mexico ${ }^{(19)}$ could explain this gain of diversity. A trace-back analysis of the extant cattle populations in those regions could be footprints in the way to explain the major ancestors of the Mexican Llaguno family.

\section{Acknowledgements}

Thanks to the Lidia breeders associations of Mexico, Spain and to all the breeders who kindly provided the biological material used in this study. Financial support received by the Consejo Nacional de los Recursos Genéticos Pecuarios and Consejo Nacional de Ciencia y Tecnología from México and by the Genetics Laboratory of the Animal Production Department at the Universidad Complutense of Madrid is deeply acknowledged. Finally thanks to Hannah Colder for her English interpretation and translation services. 


\section{- Cited literature}

1. Wilson DE, Reeder DM editors. Mammal species of the world: a taxonomic and geographic reference. JHU Press; 2005.

2. Maudet JB. Terres de taureaux: les jeux taurins de L'Europe à L'Amerique. Madrid: Casa de Velázquez; 2010.

3. Felius M, Beerling ML, Buchanan DS, Theunissen B, Koolmees PA, Lenstra JA. On the history of cattle genetic resources. Diversity 2014;6(Suppl 4):705-750.

4. Saumade F. Des sauvages en Occident: les cultures tauromachiques en Camargue et en Andalousie. France: Éditions de la Maison des sciences de l'homme; 2014.

5. Digard JP. L'homme et les animaux domestiques: anthropologie d'une passion Paris: Fayard; 1990:151-179.

6. Cañón J, Tupac-Yupanqui I, Garcia-Atance MA, Cortés O, Garcia D, Fernandez J, Dunner S. Genetic variation within the Lidia bovine breed. Anim Genet 2008;39:439445.

7. Cortés O, Sevane N, Baro JA, Cañón J. Pedigree analysis of a highly fragmented population, the Lidia cattle breed. Livest Sci 2014;167:1-8.

8. Niño de Rivera L. Sangre de Llaguno, la razón de ser del toro bravo mexicano. México: Punto de Lectura. 2004.

9. ANCTL. Asociacion Nacional de Criadores de Toros de Lidia. México. 2016.

10. Eusebi PG, Cortés O, Dunner S, Cañón J. Genetic diversity of the Mexican Lidia bovine breed and its divergence from the Spanish population. J Anim Breed Genet 2017: 332339.

11. Dunner S. Cañón J. Solution for the indefinite maintenance of nucleic acids in the cell of origin thereof. 2006: Patent WO 2006/040376.

12. Sambrook J, Fritsch EF, Maniatis T. Molecular cloning: A laboratory manual. 2nd ed. NY, USA: Cold Spring Harbor Laboratory Press; 1989.

13. Purcell SM, Neale B, Todd-Brown K, Thomas L, Ferreira M, et al. PLINK: A tool set for whole-genome association and population-based linkage analyses. Am J Human Genet 2007;81:559-575. 
14. Belkhir K, Borsa P, Chikhi L, Raufaste N, Bonhomme F. GENETIX 4.05, logicielsous Windows TM pour la génétique des populations. Laboratoire Génome, Populations, Interactions CNRS.UPR. 9060. 1996;5000:1996-2004.

15. Pritchard JK, Stephens M, Donnelly P. Inference of population structure using multilocus genotype data. Genetics 2000;155:945-59.

16. Rosenberg NA. Distruct: a program for the graphical display of population structure. Mol Ecol Notes 2004;4:137-138.

17. Wright S. The genetical structure of populations. Ann Eugen 1951;15: 323-354.

18. Martín GV. Victorino por Victorino. Madrid: Espasa Libros. 2000.

19. Censo Agrícola, Ganadero y Forestal 2007. INEGI. http://www.inegi.org.mx. Consultado Dic 15, 2016. 